Sławomir Pawłowski SAC

Katolicki Uniwersytet Lubelski

\title{
Czy istnieje „hierarchia soborów”? Perspektywa ekumeniczna
}

Jeżeli stwierdza się istnienie „hierarchii prawd wiary” ${ }^{1}$ dyskutuje się o „hierarchii sakramentów”, to czy można mówić także o „hierarchii soborów”?

\section{Pierwszeństwo pierwszych czterech soborów powszechnych? Uprzywilejowane miejsce I Soboru w Nicei?}

W 1960 roku, w okresie przygotowań do II Soboru Watykańskiego, ukazało się zbiorowe dzieło Le Concile et les conciles ${ }^{3}$ - „Sobór i sobory”.

${ }^{1}$ Por. Sobór Watykański II, Dekret o ekumenizmie „Unitatis redintegratio”(21 listopada 1964), nr 11. Zob. W. Hryniewicz, „Hierarchia veritatum” - wspólne dobro podzielonego chrześcijaństwa, [w:] Święta tajemnica jedności, red. W. Hryniewicz, P. Jaskóła, Lublin 1988, s. 37-64; S. Pawłowski, Zasada hierarchii prawd wiary. Studium ekumeniczno-dogmatyczne na podstawie najnowszej myśli teologicznej (1984-2003), Lublin 2004.

${ }^{2}$ Zob. Y. Congar, Idea sakramentów większych, czyli głównych, „Concilium” 1-10 (1968) s. 9-17.

${ }^{3}$ Zob. B. Botte i in., Le Concile et les conciles. Contribution à l'histoire de la vie conciliaire de l'Église, Paris 1960: Éditions de Chevetogne, Éditions du Cerf. Nie podano 
Teologowie odłożyli swoje bieżące prace i w poczuciu obowiązku względem Kościoła podjęli temat, którym od stycznia 1959 roku żył cały chrześcijański świat - nowy sobór. W publikacji poruszono zagadnienia historyczno-teologiczne związane z synodami przednicejskimi, z soborami starożytności i średniowiecza, a także z Soborem Trydenckim i Soborem Watykańskim 1869-1870 roku (w 1960 roku nie nazywano go jeszcze „Pierwszym”). Dzieło wieńczy wspaniałe podsumowanie, które wyszło spod pióra Yves'a Congara. Zbiera on punkty zgody i różnicy zdań między Wschodem i Zachodem, między protestantami i katolikami, i wskazuje na zagadnienia szczególnie ważne w teologii soborów: kolegialność Kościoła a prymat papieski, ekumeniczność i historyczność soborów, związek Pisma Świętego i Tradycji z autorytetem soborów i inne ${ }^{4}$. Umieszczony w Le Concile et les conciles artykuł Congara na temat pierwszeństwa pierwszych czterech soborów powszechnych ${ }^{5}$ pozostaje opracowaniem klasycznym po dziś dzień.

Formowanie się swoistego kanonu pierwszych czterech soborów miało miejsce jeszcze przed piątym soborem powszechnym (II Sobór w Konstantynopolu - 553). Przyczynił się do tego spór o teopaschizm ${ }^{6}$, w którym chodziło o właściwy sens i autorytet

redaktora (redaktorów) tej pracy zbiorowej, ale na stronie tytułowej widnieją nazwiska autorów poszczególnych rozdziałów (artykułów): B. Botte, H. Marot, P.-Th. Camelot, Y. Congar, H. Alivisatos (teolog prawosławny z Uniwersytetu Ateńskiego), G. Fransen, P. de Vooght, J. Gill, A. Dupront, R. Aubert. Wprowadzenie, napisane przez o. Rousseau, zostało zaopatrzone notatką: „Chevetogne, Niedziela Ojców pierwszego soboru ekumenicznego w Nicei, 29 maja 1960".

${ }^{4}$ Por. Y. Congar, Conclusion, [w:] B. Botte i in., Le Concile et les conciles..., dz.cyt., s. 285-334.

${ }^{5}$ Por. Y. Congar, La primauté des quatre premiers conciles œcuméniques. Origine, destin, sens et portée d'un thème traditionnel, [w:] B. Botte i in., Le Concile et les conciles..., dz.cyt., s. 75-109.

${ }^{6}$ Teopaschizm, lub teopaschazjanizm, to pogląd teologiczny uznający, że Jezus Chrystus cierpiał i umierał na krzyżu jako Bóg. Najpierw był wyrażony w formule „Jeden z Trójcy Świętej został ukrzyżowany”, na której ukucie miał wpływ patriarcha Konstantynopola Proklus (zm. 446). Formuła wywołała spór, 
nauczania soborów w Efezie (431) i w Chalcedonie (451). Wpływ na ukształtowanie się tego kanonu miały również starania o zakończenie tzw. schizmy akacjańskiej między Rzymem a Konstantynopolem (484-519) i uznanie przez chrześcijański Zachód powszechności Soboru w Konstantynopolu (381) 7 . Wówczas papież Hormizdas (514523) w 519 lub w 520 roku uzupełnia dekret przypisywany papieżowi Gelazemu (492-496) na temat kanonicznych i niekanonicznych ksiąg Pisma Świętego, jak również dzieł Ojców Kościoła i pisarzy kościelnych, które trzeba przyjąć lub odrzucić. Hormizdas dodaje wzmiankę o Soborze w Konstantynopolu i wyraźnie wymienia liczbę „cztery”.

zaostrzony w latach 518-519 za sprawą mnichów scytyjskich, propagatorów teopaschizmu, popieranych na dworze cesarza Justyna I (518-527) przez Justyniana, późniejszego cesarza (527-565). Na formułę nie chciał zgodzić się ówczesny patriarcha Konstantynopola Jan II (518-520). W istocie chodziło o rozbieżności między stanowiskiem antiocheńskim a aleksandryjskim w rozumieniu zasady communicatio idiomatum. Papież Hormizdas zaproponował formułę: ,jedna osoba Trójcy cierpiała w ciele", która została zaakceptowana przez strony sporu w 519 roku. Kontrowersja teopaschiczna odrodziła się jeszcze za pontyfikatu papieża Jana II (533-535). Por. J. Pałucki, Jan II, [w:] Encyklopedia katolicka, t. 7, Lublin 1997, k. 825n; B. Modzelewska, Jan II, [w:] Encyklopedia katolicka, t. 7, dz.cyt., k. 863; M. Szram, Teopaschizn, teopaschazjanizm, [w:] Encyklopedia katolicka, t. 19, Lublin 2013, k. 622n; B. Altaner, A. Stuiber, Patrologia. Życie, pisma i nauka Ojców Kościoła, tłum. P. Pachciarek, Warszawa 1990, s. 453.

${ }^{7} \mathrm{Na}$ Wschodzie dopiero od Soboru w Chalcedonie (451) synod biskupów w Konstantynopolu (381) zaczyna być zaliczany do soborów powszechnych, natomiast Zachód miał trudność z uznaniem powszechności tego soboru aż do 519 roku. Por. M. Starowieyski, Sobory Kościoła niepodzielonego. Część I - Dzieje, Tarnów 1994, s. 34; Y. Congar, La primauté des quatre premiers conciles œecuméniques, dz. cyt., s. 75.

8 „Et quamvis aliud fundamentum nullus potuit ponere, praeter id quod positum est, quod est Christus Jesus; tamen ad aedificationem nostram eadem Romana Ecclesia, post illas Veteris vel Novi Testamenti, quas regulariter superius enumeravimus, etiam has suscipi non prohibet scripturas. Id est sanctam synodum Nicaenam, secundum trecentos decem et octo Patres, mediante maximo Constantino Augusto; in qua Arius haereticus condemnatus est. Sanctam synodum Constantinopolitanam, mediante Theodosio Seniore Augusto; in qua Macedonius haereticus debitam damnationem excepit. Sanctam synodum Ephesinam, in qua Nestorius damnatus est consensu beatissimi Coelestini papae, mediante Cyrillo Alexandrinae sedis antistite: et Arcadio episcopo ab Italia destinato. Sanctam synodum Chalcedonensem, 
W czasie sporów o teopaschizm pojawiło się również porównanie czterech soborów do czterech Ewangelii. Teodor, opat mnichów palestyńskich wiernych soborowi w Chalcedonie, miał powiedzieć podczas zebrania w Jerozolimie w 516 roku: „Jeżeli ktoś nie przyjmuje czterech soborów jak czterech Ewangelii, niech będzie wyklęty"9. Ta analogia stanie się jeszcze bardziej znana przez list papieża Grzegorza I Wielkiego do patriarchów Konstantynopola, Aleksandrii, Antiochii i Jerozolimy, napisany w 591 roku, a zatem wiele lat po piątym soborze (553): „Jak cztery księgi świętej Ewangelii, tak cztery sobory przyjmuję i obdarzam czcią [...]. Piąty sobór równie czczę [...], ponieważ opierają się na powszechnym uznaniu [...]"10.

Z tego i innych pism św. Grzegorza Wielkiego wynika, że pierwsze cztery sobory mają walor kryterium. Piąty sobór - którego recepcja na Zachodzie była trudna chociażby z powodu kwestii Trzech

mediante Marciano Augusto, et Anatolio Constantinopolitano episcopo; in qua Nestoriana et Eutychiana haeresis, simul cum Dioscoro ejusque complicibus damnatae sunt. Sed et si qua sunt concilia a sanctis Patribus hactenus instituta, post istorum quatuor auctoritatem et custodienda et recipienda decrevimus" (podkreślono zdania dodane przez papieża Hormizdasa). Cyt. za: Decree of Pope Hormisdas on Canonical and Noncanonical Books (A.D. 520): http://www.christiantruth.com/arti cles/hormisdasdecretum.html (4.01.2016).

Ten tekst w skróconej formie odnajdziemy przy prezentacji Dekretu Gelazego, [w:] H. Denzinger, A. Schönmetzer, Enchiridion symbolorum, definitionum et declarationum de rebus fidei et morum, Barcinone-Freiburg-Romae 1965, s. 123 (DS 352). Podkreślone wyżej zdania zostały tam umieszczone w nawiasie z przypisem: „Sine dubio non ante finem schismatis Acaciani (a. 519) insertum".

${ }^{9}$ E. Schwartz, Kyrillos von Scythopolis, Leipzig 1939, s. 152; cyt. za: Y. Congar, La primauté des quatre premiers conciles œcuméniques, dz.cyt., s. 76. Cyryl ze Scytopolis (ok. 524-560) jest autorem biografii poświęconych mnichom palestyńskim lat 450550. Jego dzieła zawierają także wiele informacji na temat sporów teologicznych tamtego czasu. Por. A. Bober, Cyryl ze Scytopolis, [w:] Encyklopedia katolicka, t. 3, Lublin 1979, k. 715.

${ }^{10}$ „Sicut sancti Evangelii quattuor libros, sic quattuor concilia suscipere et venerari me fateor: Nicaenum scilicet [...]; Constantinopolitanum quoque [...] Ephesenum etiam primum [...], Chalcedonense vero [...]. Quintum quoque concilium pariter veneror [...] quia dum universali sunt consensu constituta [...]. Quisquis ergo aliud sapit, anathema sit". DS 472. 
Rozdziałów $w^{11}$ - nie ma prawa do podobnego respektu, chyba że z racji zgodności z czterema poprzednimi. Bez wątpienia na początku VII wieku pierwsze cztery sobory są uważane za te, które sformułowały „wiarę" i przedstawiają istotną normę i fundament prawowierności ${ }^{12}$.

Podobny wniosek wyciągniemy z pism św. Izydora z Sewilli (zm. 636) oraz z wyznań wiary synodów w Toledo $(589,633)$. To właśnie św. Izydor porównuje pierwsze cztery sobory do czterech rzek raju (Rdz 2, 9n) ${ }^{13}$.

Hinkmar, biskup Reims, w swoim wyznaniu wiary z 845 roku uznaje sześć soborów powszechnych (bez II Soboru Nicejskiego z 787), ale pierwsze cztery uważa za "główne” (concilia principalia), a z nich największą czcią darzy Sobór w Nicei z 325 roku, nazywając go „mistycznym” (mystica synodus), czyli przepełnionym misteriami zbawienia. Podobnie wiele symboli wiary, lokalnych synodów czy biskupów aż do początku XII w. uznaje hierarchię soborów, nie w sensie ekskluzywnym, ale w sensie pozytywnej wartości przywileju pierwszych czterech soborów ${ }^{14}$.

${ }^{11}$ Tak nazwano problem trzech pisarzy kościelnych - Teodora z Mopsuestii (zm. 428), Ibasa z Edessy (zm. 457) i Teodoreta z Cyru (zm. 466) - „domniemanych ojców nestorianizmu", których prawowierność zakwestionowano już po ich śmierci w otoczeniu cesarza Justyniana, aby pozyskać monofizytów. Współcześni badacze na ogół przyjmują ich ortodoksyjność. Pomimo niegodnych metod stosowanych przez cesarza i chwiejnego stanowiska Wigiliusza (papież w latach 537-555) II Sobór w Konstantynopolu obronił autorytet Soboru Chalcedońskiego i pogłębił jego teologię. Por. M. Starowieyski, Sobory Kościoła niepodzielonego, dz.cyt., s. 79-94. O II Soborze Konstantynopolitańskim i jego rzymskokatolickiej recepcji świadczy wymownie wyznanie wiary dla maronitów papieża Benedykta XIV z 1743 roku. Papież wylicza poszczególne sobory, wymieniając potępione herezje i ich zwolenników, a także główne definicje wiary (DS 2525-2540), ale przy piątym soborze daje tylko jedno krótkie zdanie: „[...] in qua praefatae Chalcedonensis Synodi definitio renovata est" (DS 2530).

12 Por. Y. Congar, La primauté des quatre premiers conciles cecuméniques, dz.cyt., s. 78-80.

${ }^{13}$ Por. tamże, s. 80-82.

${ }^{14}$ Por. tamże, s. 83-86. 
Wraz z reformą kościelną ostatniego trzydziestolecia XI wieku zaczyna się wyczuwać na Zachodzie zmianę klimatu eklezjologicznego. Coraz bardziej akcentuje się fakt, że pierwsze cztery sobory były zaaprobowane przez papieży. Niemniej jednak ciągle idea ich pierwszeństwa jest silna, czego przykładem są pisma Gracjana, Abelarda i Piotra Lombarda ${ }^{15}$.

Marcin Luter nazywał pierwsze cztery sobory „wielkimi” i „głównymi" (die vier grosse heubt Concilia). Uczynił tak w dziele Von den Conciliis und Kirchen (1539), w obliczu zwołania soboru przez papieża Pawła III. Dopuszcza on ich naukę, ale nie z racji ich autorytetu własnego, lecz z powodu afirmacji tego, w co już wierzono, bo żaden sobór, zdaniem Lutra, nie może promulgować nowego dogmatu ${ }^{16}$.

Kalwin, podobnie, uznaje wyjątkową wartość czterech pierwszych soborów. Nie posiadają one dla niego wartości normatywnej same z siebie, lecz czerpią ją ze stopnia zgodności swojej nauki z Pismem Świętym. Co prawda Kalwin uznaje je tylko „materialnie", stwierdza Congar, czyli tylko pod względem treści, ponieważ po ich wyliczeniu dodaje „oraz im podobnych” (ac similes) ${ }^{17}$. II Konfesja Helwecka z 1566 roku stwierdza: „wierzymy szczerym sercem $\mathrm{w}$ to, co o misterium wcielenia Chrystusa zdefiniowano na podstawie Pisma Świętego i zebrano w symbolach jak i postanowieniach quatuor primarum et praestantissimarum Synodorum, jak też w symbolu Atanazego i wszystkich im podobnym" (art. XI) ${ }^{18}$.

${ }^{15}$ Por. tamże, s. 87-96.

16 Por. tamże, s. 96.

17 „Sic priscas illas synodos ut Nicenam, Constantinopolitanam, Ephesinam primam, Chalcedonensem ac similes, quae confutandis erroribus habitae sunt, libenter amplectimur, reveremur ut sacrosanctas, quantum attinent ad fidei dogmata: nihil enim continent quam puram et nativam Scripturae interpretationem [...]". Kalwin, Institutio religionis christianae (wydanie z 1559), IV, IX, 8. Cyt. za: Y. Congar, La primauté des quatre premiers conciles œcuméniques, dz. cyt., s. 97.

${ }_{18}$ Podaję za: Y. Congar, La primauté des quatre premiers conciles œcuméniques, dz. cyt., s. 97 . 
Według Congara formuły anglikańskie są przychylne kanonowi czterech soborów, ale w sensie ekskluzywnym. Mamy tutaj dużo odniesień, np. w Dziesięciu Artykułach Henryka VIII (1536), w Bishop's Book (1537), w Reformatio legum ecclesiasticorum (1553), w Akcie Supremacji (1559) ${ }^{19}$. W rozdziale XIV Reformatio legum ecclesiasticorum, gdzie uznaje się autorytet czterech głównych soborów (quatuor praecipua) ${ }^{20}$, mówi się dalej, że inne sobory mogą błądzić. Stwierdzenie o możliwości i fakcie błądzenia soborów zostało podjęte w artykule 21 Trzydziestu dziewięciu artykułów anglikańskich z 1563 roku (rok zakończenia Soboru Trydenckiego!), ale bez wymienienia pierwszych czterech soborów. Późniejsze anglikańskie Konferencje w Lambeth $(1867,1888)$ podjęły kryterium czterech soborów. Osobnym, ale nieodizolowanym zagadnieniem byłaby tutaj także kwestia idei „zgody pięciu wieków” - consensus quinquesaecularis $^{21}$, z różnymi jej wariantami w anglikanizmie i w protestantyzmie, czego dokumentacja jest niezmiernie obfita ${ }^{22}$. Warto dodać, że przekonanie o wartości pierwszychczterech soborów pozostaje nadal żywe w myśli ewangelickiej, aczkolwiek zostało nieco przytłumione protestancką teologią liberalną ${ }^{23}$.

Teologowie katoliccy epoki reformacji przyjmowali jeszcze chętnie tradycję czterech soborów. Przykładem może być Merlin (zm. 1541), który wydał w 1530 roku kolekcję, której pierwszy tom był zatytułowany: Conciliorum quatuor generalium... Que divus Gregorius Magnus tanquam quatuor Evangelia colit ac veneratur. Po Soborze

${ }^{19}$ Por. tamże, s. 98.

20 „Nam quaedam illorum, qualia sunt praecipua illa quatuor, Nicenum, CPum Primus, Ephesinum et Chalcedonensae, magna cum reverentia amplectimur et suscipimus". Cyt. za: Y. Congar, La primauté des quatre premiers conciles œcuméniques, dz.cyt., s. 98.

${ }^{21}$ Termin ukuty przez Johna Georga Dorscha (1597-1654).

${ }^{22}$ Por. Y. Congar, La primauté des quatre premiers conciles œecuméniques, dz.cyt., s. 98 n.

${ }^{23}$ Por. W. Hryniewicz, „Hierarchia prawd” w tradycji chrześcijańskiej, „Zeszyty Naukowe KUL" 17 (1974) z. 3, s. 69n. 
Trydenckim kanon pierwszych czterech soborów przestaje odgrywać znaczącą rolę wśród teologów katolickich, z wyjątkiem teologów nurtu gallikańskiego. Potrydencka teologia katolicka rozwija aktywny aspekt żywego Magisterium, który odnosi się do wszystkich definicji wiary. Wyznanie wiary dla maronitów papieża Benedykta XIV z 1743 roku (DS 2525-2540) wylicza sobory starożytności, średniowiecza i nowożytności, aż po Sobór Trydencki, nazywając je wszystkie universales synodes. Ciekawe jednak, że sobory średniowiecza wymienia tylko ogólnie jako alias universalem Synodos auctoritate Romani Pontificis legitime celebratas et confirmatas, z wyjątkiem specjalnej wzmianki o Soborze Florenckim (praesertim Florentinam Synodum - DS 2534) ${ }^{24}$.

Jakie jest - oprócz symboliki liczby cztery, szeroko opisanej przez Congara $^{25}$ - znaczenie „kanonu czterech soborów”? W tradycji katolickiej uprzywilejowane miejsce pierwszych czterech soborów nie ma znaczenia ekskluzywnego w odniesieniu do pozostałych soborów. Congar porównuje to do idei „sakramentów większych” czy koncepcji „głównych dogmatów”. Afirmacja sakramentów większych (chrztu i Eucharystii) nie ujmuje nic sakramentalności pozostałych sakramentów, tak jak główne dogmaty (o Trójcy i Chrystusie) nie pozbawiają autorytetu pozostałych. Dogmaty, sakramenty i sobory należy rozważać jednak nie tylko pod względem ich autorytetu, ich strony formalnej (scholastyczne quo), ale także pod względem ich treści, ich związku z objawieniem i dziełem zbawienia. Nie można umieszczać wszystkiego na jednej płaszczyźnie. Istnieje hierarchia, którą trzeba uszanować ${ }^{26}$.

${ }^{24}$ Por. Y. Congar, La primauté des quatre premiers conciles œeuméniques, dz.cyt., s. 99 n.

${ }^{25}$ Por. tamże, s. 101-104.

${ }^{26}$ Por. tamże, s. 106n. Zdanie, które warto zacytować w całości: „Mais il y a lieu de considérer aussi leur contenu, leur rapport au centre de la Révélation et de l'œvre salutaire. A cet égard, on ne saurait tout mettre sur le même plan, il y a des perspectives à ménager, une hierarchie à respecter". Tamże, s. 107. W tej myśli 
Wydaje się, że chrześcijański Wschód praktykował kanon czterech soborów mniej niż Zachód, którego pedagogami byli św. Grzegorz Wielki i św. Izydor. Jednakże pierwszy szkic tego kanonu pochodzi ze Wschodu. Ponadto teologia wschodnia posiada siłę kierowania wszystkich punktów doktryny do centrum zakorzenionego w dogmacie trynitarnym i chrystologicznym, które były przedmiotem uchwał tych soborów. Z drugiej strony wiemy, że Kościół prawosławny, uznając autorytet pierwszych siedmiu soborów powszechnych, w specjalny sposób czci w liturgii święto I Soboru Nicejskiego (325), Soboru Chalcedońskiego (451) i II Soboru Nicejskiego (787). Czy nie jest to, pyta Congar, pozytywny i głęboki ekwiwalent kanonu czterech soborów, przeżywany w sposób odpowiadający misteryjnemu geniuszowi Kościoła wschodniego ${ }^{27}$

Czy to jedyna hierarchizacja soborów? Pośród pierwszych czterech soborów szczególnie uprzywilejowany jest I Sobór Nicejski (325). Cztery sobory stanowią rodzaj kryterium i normatywny punkt odniesienia dla pozostałych, bo sformułowały wiarę, w której wyznawaniu chrześcijanin jest ochrzczony, zjednoczony z Bogiem, zbawiony, ale wśród nich Sobór Nicejski 325 roku jest pierwszy w sposób fundamentalny i decydujący. Wszystkie kolejne nie tylko następują po nim materialnie, lecz także powinny być na nim budowane. Jest na to wiele świadectw, których zacytowanie zajęłoby tyle miejsca, co artykuł o czterech soborach, stwierdza Congar ${ }^{28}$.

W całości tradycji ani papieże, ani teologowie, ani nawet same sobory nie umieszczały siebie na jednej płaszczyźnie, konkluduje Congar, również te sobory, które dzisiaj określamy mianem tej samej kategorii powszechności jako „ekumeniczne”. Ważne jest, aby

Congara z 1960 roku znajduje się teologiczna podstawa soborowej nauki o hierarchii prawd wyrażonej w Dekrecie o ekumenizmie z 1964 roku (nr 11).

${ }^{27}$ Por. Y. Congar, La primauté des quatre premiers conciles œcuméniques, dz. cyt., s. $107 n$.

${ }^{28}$ Por. tamże, s. 108. Wśród kilku przykładowych świadectw Congar podaje fragment listu papieża Mikołaja I z 866 roku do Bułgarów (Mansi XV, 430): „Nicaena synodus, quae cunctis synodis celebrior et venerabilior est". 
dopuścić na poziomie zasad samą możliwość jakiegoś porządku soborów ${ }^{29}$.

\section{Sobory „powszechne” i „ogólne”, „większe” i „mniejsze”? Ekumeniczność de facto i de iure?}

Szerokim echem odbił się list papieża Pawła VI z okazji obchodów siedemsetnej rocznicy II Soboru Lyońskiego (1274). Papież, w piśmie z 5 października 1974 roku skierowanym do kardynała Johannesa Willebrandsa ${ }^{30}$, nazwał ten sobór „drugim lyońskim soborem generalnym” i „szóstym synodem generalnym celebrowanym na Zachodzie" ${ }^{31}$. Teologowie zwrócili uwagę nie tyle na użycie słowa synodus, które w języku łacińskim jest synonimem concilium, ile na zastosowanie przymiotnika generale (generalny, ogólny) zamiast œecumenicum ${ }^{32}$.

Idea, która kryje się w terminologii zastosowanej przez Pawła VI, nie była zupełnie nowa. Już wspomniany wcześniej artykuł Congara z 1960 roku o pierwszeństwie pierwszych czterech soborów zawierał krótką notkę o dodatkowym rozróżnieniu soborów na „ekumeniczne" i „generalne” (ogólne). Congar wspomina, że była to propozycja

${ }^{29}$ Por. Y. Congar, La primauté des quatre premiers conciles œcuméniques, dz.cyt., s. 109.

${ }^{30}$ Por. Paulus PP. VI, Epistula. E. mo P. D. Ioanni S. R. E. Cardinali Willebrands (...) ut Lugduni celebritatibus praesideat, septimo expleto saeculo ex quo alterum Generale Concilium Lugdunense actum est, „Acta Apostolicae Sedis” 66 (1974), s. 620-625.

${ }^{31}$ W oryginale: „[...] alterum Generale Concilium Lugdunense [...]” oraz „Hoc Lugdunense Concilium, quod sextum recensetur inter Generales Synodos in Occidentali orbe celebratas [...]". Tamże, s. 620.

32 Por. W. Hryniewicz, Kościoły siostrzane. Dialog katolicko-prawosławny 19801991, Warszawa 1993, s. 22; L. Sartori, I principi cattolici dell'ecumenismo alla luce dell'esperienza di 20 anni, „Studi Ecumenici” 2 (1984) s. 477; E. Lanne, „Dekret o ekumenizmie" jako punkt wyjścia rozwoju katolickiej świadomości ekumenicznej, [w:] Święta tajemnica jedności, dz.cyt., s. 161. 
Venance'a Grumela ${ }^{33}$, ale dodaje, że już jeden z uczestników soboru we Florencji (1439-1445), łaciński arcybiskup Krety Fantinus Vallaresso, rozróżnia sobory ekumeniczne, które jednoczyły Kościoły Wschodu i Zachodu (utraque ecclesia), i kanonicznie zwołane przez papieży sobory generalne. $\mathrm{W}$ ten sposób Vallaresso wylicza tylko osiem soborów ekumenicznych przed Soborem Florenckim ${ }^{34}$. W literaturze teologicznej wymienia się Darwella Stone'a (1859-1941) jako tego, który wprowadził rozróżnienie między soborem „generalnym” a „powszechnym”. Choć w obu przypadkach reprezentacja Kościoła mogła być jednakowo powszechna, to jednak sobór generalny nie wyrażał świadomości Kościoła w sposób powszechny ${ }^{35}$.

Wspomniany już Grumel (1890-1967) zwraca uwagę na różnicę między soborami, których decyzje dotyczyły wprost prawdy objawionej, a soborami, które podejmowały kwestie związane $\mathrm{z}$ wiarą, ale nie wprost objawione lub zajmowały się sprawami dyscypliny kościelnej, jak to miało miejsce w soborach średniowiecza. Grumel zaproponował, by nazwać sobory pierwszego typu „pierwszorzędnymi” lub „większymi”, a pozostałe „drugorzędnymi” lub „mniejszymi”"

Współcześni teologowie zwracają uwagę na „awans”, którego doznały zachodnie sobory średniowiecza przez sposób liczenia soborów utrwalony w Kościele katolickim dopiero od czasów św. Roberta Bellarmina (1595). Lista, opracowana wtedy celem przygotowywania druku publikacji poświęconej soborom, uznaje sobory starożytności,

${ }^{33}$ Por. V. Grumel, L'union des Églises et le nombre des Conciles œecuméniques, „L'Unité de l'Église"11 (1933) janv.-fevr., s. 5-7.

${ }^{34}$ Congar wskazuje na Libellus de ordine generalium conciliorum et unione Florentina autorstwa Vallaresso (ok. 1443), opublikowany przez B. Schultze (Concilium Florentinum, II/2, Roma 1944) oraz artykuł B. Schultze, Das letzte ökumenische Einigungskonzil theologisch gesehen, „Orientalia Christiana Periodica” 25 (1959), s. 288-309. Terminologia użyta przez Vallaresso wymaga jednak dalszej analizy.

35 Por. D. Stone, The Christian Church, London 1915, s. 355. Podaję za: NSO, s. 117.

${ }^{36}$ Por. V. Grumel, L'union des Églises et le nombre des Conciles œcuméniques, s. 5. Podaję za: NSO, s. 117. 
średniowiecza i wczesnej nowożytności (do Trydenckiego włącznie) za concilia generalia aprobata. Wcześniej na Zachodzie nigdy soborów średniowiecza nie stawiano na jednej płaszczyźnie z siedmioma soborami ekumenicznymi starożytności ${ }^{37}$.

Joseph Ratzinger stwierdza, że prymat soborów starożytnych nie wynika z ich starszeństwa czasowego, ale z podjęcia centralnych artykułów wiary. Mówiąc o soborach średniowiecza, rozróżnia między ich ekumenicznością „z prawa” (de iure) a ich ekumenicznością „faktyczną" (de facto). Ta pierwsza jest zapewniona przez prymat papieski, dlatego tych soborów nie można sprowadzić do rangi synodów lokalnych. Niemniej jednak ich ekumeniczność faktyczna jest naznaczona głębokim brakiem z racji nieobecności Kościołów wschodnich, stwierdza Ratzinger. W podobny sposób inni teologowie rozróżniają między ekumenicznością „formalną” i „materialną" soborów ${ }^{38}$.

Tutaj pojawia się miejsce na dowartościowanie zjawiska kościelnej recepcji soborów. Teologowie katoliccy podkreślają, że obecna lista soborów powszechnych (21 soborów wraz z II Soborem Watykańskim) nie została oficjalnie ogłoszona przez Magisterium Kościoła ${ }^{39}$. Choć uznanie prawomocności soboru powszechnego ma charakter aktu definitywnego ${ }^{40}$, to jednak nie istnieje dotychczas żadna enumeratywna lista soborów ${ }^{41}$. Skoro liczba 21 nie jest

${ }^{37}$ Por. L. Bouyer, Kościół Boży: Mistyczne Ciało Chrystusa i światynia Ducha Bożego, Warszawa 1977, s. 568; S. C. Napiórkowski, Jak uprawiaćteologię, Wrocław 2002, s. 205207; NSO, s. 116.

${ }^{38}$ Por. J. Ratzinger (z P. Nemeshegyi, Ph. Delhayes), Quinze thèses sur l'unité de la foi et le pluralisme théologique, Paris 1978, s. 53; B. de Margerie, L'analogie dans l'œecuménicité des conciles notion clef pour l'avenir de l'œcuménisme, „Revue Thomiste” 84 (1984) nr 3, s. 425-445. Podaję za: NSO, s. 118.

${ }^{39}$ Por. Y. Congar, La primauté des quatre premiers conciles œecuméniques, dz.cyt., s. 109; NSO, s. 115.

${ }^{40}$ Por. Kongregacja Nauki Wiary, Wyjaśnienie doktrynalne dotyczace końcowej części formuły „Wyznania wiary”, „L'Oservatore Romano” (wyd. pol.) 19 (1998) nr 10, s. 18.

${ }^{41}$ Za taką listę nie można uznać np. dołączonego do Katechizmu Kościoła katolickiego indeksu źródeł, skoro w części poświęconej soborom powszechnym (s. 686-692 
w Kościele katolickim numerus clausus, możliwe jest uznanie kolejnych soborów. Zdaniem Wacława Hryniewicza, niełatwo jest usprawiedliwić fakt wycofania uznania tzw. synodu focjańskiego (879-880) na korzyść synodu ignacjańskiego, uznanego za IV Sobór Konstantynopolitański (869-870). Uznanie synodu focjańskiego za sobór powszechny przez Kościół katolicki i Kościół prawosławny byłoby doniosłym wkładem $\mathrm{w}$ dzieło zjednoczenia i usunęło wiele eklezjologicznych rozbieżności, stwierdza Hryniewicz ${ }^{42}$. Niemniej jednak niektórzy teologowie prawosławni uznają pierwsze siedem soborów za liczbę nienaruszoną ${ }^{43}$.

\section{Ekumeniczny głos teologów: dla większości tradycji - szczególne pierwszeństwo siedmiu soborów}

Wspólna Grupa Robocza Światowej Rady Kościołów i Kościoła Rzymskokatolickiego powstała w końcowym okresie obrad II Soboru Watykańskiego, w lutym 1965 roku. Jako pierwsza w historii struktura umożliwiająca spotkanie się teologów całego chrześcijaństwa omówiła wiele ważnych zagadnień teoretycznych i praktycznych ekumenizmu. W 25. rocznicę swej działalności, podczas sesji plenarnej odbytej w dniach 25 stycznia - 2 lutego 1990 roku w Rzymie, Wspólna Grupa Robocza zatwierdziła swój Szósty Raport ${ }^{44}$, do którego

według polskiego II wydania poprawionego: Poznań 2002) nie zawiera czterech uznawanych przez Kościół katolicki: I Laterańskiego (1123), II Laterańskiego (1139), III Laterańskiego (1180) i I Lyońskiego (1245). Katechizm po prostu nie zawiera żadnych cytatów czy odniesień do tych soborów średniowiecza.

${ }^{42}$ Por. W. Hryniewicz, Focjański Synod, [w:] Encyklopedia katolicka, t. 5, Lublin 1989, k. 353-356. Przypomnijmy, że uznany za sobór synod ignacjański rozpoczęło tylko 12 biskupów (sic!), których ilość wzrosła potem do 38; zaś synod focjański rozpoczęło aż 383 biskupów. Por. M. Starowieyski, Sobory Kościoła niepodzielonego, dz. cyt., s. $140-143$.

${ }^{43}$ Por. NSO, s. 127.

${ }^{44}$ Wspólna Grupa Robocza Kościoła Rzymskokatolickiego i Światowej Rady Kościołów, Szósty Oficjalny Raport (1990), „Studia i Dokumenty Ekumeniczne” 8 (1992) nr 2, s. 47-69. 
dołączono wypracowywany od kilku lat dokument studyjny pt. Pojęcie „,hierarchii prawd"-interpretacja ekumeniczna ${ }^{45}$. W III rozdziale (nr 10) dokument stwierdza, że choć na II Soborze Watykańskim koncepcja „hierarchii” czy „porządku” prawd wiary (UR 11) była nowa, to jednak miała w historii chrześcijaństwa swoje analogie. Przykładem może być porządek pism natchnionych ${ }^{46}$, hierarchia sakramentów ${ }^{47}$, sposób przeżywania roku liturgicznego ${ }^{48}$.

W numerze 12 dokument mówi także o hierarchii soborów:

„Dostrzega się kilka rodzajów «hierarchii» w odniesieniu do autorytetu i uchwał soborów kościelnych. Większość tradycji chrześcijańskich przyznaje szczególne pierwszeństwo siedmiu soborom ekumenicznym wczesnego Kościoła. Niektórzy dopatrują się także «hierarchii» pomiędzy tymi

${ }^{45}$ Wspólna Grupa Robocza Kościoła Rzymskokatolickiego i Światowej Rady Kościołów, Pojęcie "hierarchii prawd” - interpretacja ekumeniczna. Dokument studyjny, „Studia i Dokumenty Ekumeniczne” 8 (1992) nr 2, s. 85-93. Oryginalna wersja angielska: The Notion of „Hierarchy of Truths”: An Ecumenical Interpretation. A Study Document Commisioned and Received by the Joint Working Group, Faith and Order Paper 150, WCC Publications, Genewa 1990, s. 16-24. Przytoczone poniżej tłumaczenia fragmentów dokumentu na podstawie wersji oryginalnej - SP.

${ }^{46}$ „11. Nawet jeśli Pismo św. jest natchnione przez Boga jako całość i w każdej swej części, wielu dostrzegło porządek lub «hierarchię» w tej mierze, w jakiej pewne sekcje lub teksty biblijne świadczą bardziej bezpośrednio o wypełnieniu obietnicy Boga i objawieniu w Jezusie Chrystusie przez Ducha Świętego w Kościele”. Notion of „Hierarchy of Truths”..., dz.cyt., s. 18

47 „13. Sakramenty mogłyby służyć za inny przykład «hierarchii» w obrębie tego samego porządku, który dotyczy bezpośrednio wiary. Chrzest (jaki dla niektórych zawiera bierzmowanie) jako włączenie do Kościoła i Eucharystia jako centrum życia Kościoła - były postrzegane jako podstawowe, podczas gdy inne akty sakramentalne odnoszą się do tych główniejszych sakramentów". Tamże.

48 „14. Tajemnica Jezusa Chrystusa, ujawniająca się zwłaszcza w jego śmierci i zmartwychwstaniu, znajduje się w centrum roku liturgicznego. Wszystkie celebracje w ciągu roku, jak Boże Narodzenie i Epifania, Wielkanoc i Pięćdziesiątnica, i uroczystości świętych - uwydatniają różne aspekty jedynego misterium, które jest zawsze w pełni obecne. W ten sposób różne święta roku liturgicznego, ze swoimi szczególnymi akcentami, są powiązane w różny sposób (diversus nexus) z centrum czy fundamentem - misterium Jezusa Chrystusa". Tamże. 
siedmioma soborami, uważając, że te, które sformułowały naukę o tajemnicy Chrystusa i Ducha Świętego w komunii Trójcy Świętej, powinny, jako takie, zajmować uprzywilejowane miejsce w porównaniu z innymi soborami" 49 .

Ten tekst jest ostrożnym podsumowaniem debat teologicznych na temat hierarchii soborów:

a) pierwszeństwo czterech pierwszych soborów stwierdza tylko pośrednio, gdy mówi o soborach, które sformułowały naukę „o tajemnicy Chrystusa i Ducha Świętego w komunii Trójcy Świętej”;

b) mówi wyraźnie o „pierwszeństwie siedmiu soborów ekumenicznych wczesnego Kościoła";

c) stwierdza, że nie wszystkie, ale „większość tradycji chrześcijańskich” przyznaje to pierwszeństwo siedmiu soborom;

d) nie porusza kwestii rozróżnienia soborów „ekumenicznych” i soborów „ogólnych”, chyba że pośrednio, mówiąc o pierwszeństwie siedmiu;

e) dostrzega różne hierarchie w odniesieniu do „autorytetu i uchwał" soborów.

Tę wypowiedź należy jeszcze uzupełnić o fragment nr 16 dokumentu, który prezentuje stanowisko prawosławne na temat zasady "hierarchii prawd":

„Teologowie prawosławni sugerują, że pojęcie «hierarchii prawd» mogłoby pomóc w odróżnieniu trwałego i wspólnego nauczania wiary, takiego jak ogłoszone symbole (creda) siedmiu soborów ekumenicznych i inne deklaracje wiary, od tego nauczania, które nie zostało sformułowane i usankcjonowane przez autorytet tych soborów. Tutaj może znaleźć

${ }^{49}, 12$. One sees several kinds of «hierarchies» in relation to the authority of the church councils and to their contents. Most Christian traditions give special priority to the seven ecumenical councils of the early church. Some see also a «hierarchy» among these seven councils, inasmuch as those which have formulated the doctrine of the mystery of Christ and of the Spirit within the communion of the Holy Trinity should as such hold a pre-eminent position in comparison with the other councils". Tamże. 
się miejsce na zróżnicowanie. $Z$ drugiej strony, wyłania się tu problem natury nauczycielskiego autorytetu w Kościele. Ekumenicznych rozmów na temat «hierarchii prawd» nie da się więc oddzielić od sposobów, przez które Kościół autorytatywnie formułuje prawdy i treść swojej wiary" ${ }^{50}$.

Jak echo powraca zatem sygnalizowane już zagadnienie podwójnej złożoność kwestii soborów: ich elementu formalnego i materialnego, czyli ich autorytetu i treści uchwał. Ale czyż nie odzwierciedla się tutaj swoisty „hylemorfizm” wiary: fides qua i fides quae creditur? Takjak ważny jest a kt w i a r y i jej treść, tak samo ważne jest, k to tę wiarę przekazuje (autorytet) i c z e go naucza (treść). Dyskusja o hierarchii soborów nie powinna tracić z oczu ich najgłębszej natury: są one nie tylko loci theologici, ale przede wszystkim loci fidei.

Dyskusja o hierarchii soborów nie jest zakończona i nie wiadomo nawet, czy kiedyś doprowadzi do wyraźnych rozróżnień, ale już teraz wnosi w refleksję eklezjologiczną i ekumeniczną zmysł proporcji, tak ważny dla teologii ${ }^{51}$, życia Kościoła i głoszenia Ewangeliii ${ }^{52}$.

\section{Bibliografia}

Altaner B., Stuiber A., Patrologia. Życie, pisma i nauka Ojców Kościoła, tłum. P. Pachciarek, Warszawa 1990.

Bober A., Cyryl ze Scytopolis, [w:] Encyklopedia katolicka, t. 3, Lublin 1979, k. 715 .

50 „16. [...] Orthodox theologians suggest that the concept of «hierarchy of truths» could help to distinguish permanent and common teachings of faith, such as the declared symbols (creeds) of the seven ecumenical councils and other creedal statements, from those teachings which have not been formulated and sanctioned with the authority of those councils. Here may be room for differentiation. This raises, on the other hand, the problem of the nature of the teaching authority in the church. Ecumenical discussions on «hierarchy of truths» are thus inseparable from the ways in which the church formulates authoritatively the truths and insights of its faith". Tamże.

${ }^{51}$ Por. W. Hryniewicz, „Hierarchia veritatum”..., dz. cyt., s. 45.

${ }^{52}$ Por. Franciszek, Adhortacja apostolska „Evangelii gaudium”. O głoszeniu Ewangelii w dzisiejszym świecie, Kraków 2013, nr 34-39 (rozdział III: Z serca Ewangelii). 
Botte B. i in., Le Concile et les conciles. Contribution à l'histoire de la vie conciliaire de l'Église, Paris 1960.

Congar Y., Idea sakramentów większych, czyli głównych, „Concilium” 1-10 (1968), s. 9-17.

Congar Y., La primauté des quatre premiers conciles œcuméniques. Origine, destin, sens et portée d'un thème traditionnel, [w:] Botte B. i in., Le Concile et les conciles. Contribution à l'histoire de la vie conciliaire de l'Église, Paris 1960, s. 75-109.

Denzinger H., Schönmetzer A., Enchiridion symbolorum, definitionum et declarationum de rebus fidei et morum, Barcinone-Freiburg-Romae 1965.

Franciszek, Adhortacja apostolska „Evangelii gaudium”. O głoszeniu Ewangelii w dzisiejszym świecie, Kraków 2013.

Hryniewicz W., „Hierarchia prawd” w tradycji chrześcijańskiej, „Zeszyty Naukowe KUL” 17 (1974) z. 3, s. 61-77.

Hryniewicz W., „Hierarchia veritatum” - wspólne dobro podzielonego chrześcijaństwa, [w: Święta tajemnica jedności, red. W. Hryniewicz, P. Jaskóła, Lublin 1988, s. 37-64.

Hryniewicz W., Focjański Synod, [w:] Encyklopedia katolicka, t. 5, Lublin 1989, k. 353-356.

Hryniewicz W., Kościoły siostrzane. Dialog katolicko-prawosławny 1980-1991, Warszawa 1993.

Decree of Pope Hormisdas on Canonical and Noncanonical Books (A.D. 520), http:// www.christiantruth.com/articles/hormisdasdecretum.html (4.01.2016).

Kałużny T., Nowy sobór ogólnoprawosławny. Natura, historia przygotowań, tematyka, Kraków 2008 [=NSO].

Kongregacja Nauki Wiary, Wyjaśnienie doktrynalne dotyczące końcowej części formuły „Wyznania wiary”, „L'Oservatore Romano” (wyd. pol.) 19 (1998) nr 10, s. 18.

Lanne E., „Dekret o ekumenizmie” jako punkt wyjścia rozwoju katolickiej świadomości ekumenicznej, [w:] Święta tajemnica jedności, red. W. Hryniewicz, P. Jaskóła, Lublin 1988, s. 149-165.

Modzelewska B., Jan II, [w:] Encyklopedia katolicka, t. 7, Lublin 1997, k. 863.

Pałucki J., Jan II, [w:] Encyklopedia katolicka, t. 7, Lublin 1997, k. 825-826.

Paulus PP. VI, Epistula. E. mo P. D. Ioanni S. R. E. Cardinali Willebrands (...) ut Lugduni celebritatibus praesideat, septimo expleto saeculo ex quo alterum Generale Concilium Lugdunense actum est, „Acta Apostolicae Sedis” 66 (1974), s. 620-625.

Pawłowski S., Zasada hierarchii prawd wiary. Studium ekumeniczno-dogmatyczne na podstawie najnowszej myśli teologicznej (1984-2003), Lublin 2004. 
Sartori L., I principi cattolici dell'ecumenismo alla luce dell'esperienza di 20 anni, „Studi Ecumenici” 2 (1984), s. 461-483.

Sobór Watykański II, Dekret o ekumenizmie „Unitatis redintegratio” (21 listopada 1964), [w:] Ut unum. Dokumenty Kościoła katolickiego na temat ekumenizmu 19821998, red. S. C. Napiórkowski, K. Leśniewski, J. Leśniewska, Lublin 2000, s. 11-26.

Starowieyski M., Sobory Kościoła niepodzielonego. Część I - Dzieje, Tarnów 1994.

Szram M., Teopaschizn, teopaschazjanizm, [w:] Encyklopedia katolicka, t. 19, Lublin 2013, k. 622-623.

The Notion of „Hierarchy of Truths”: An Ecumenical Interpretation. A Study Document Commisioned and Received by the Joint Working Group, Faith and Order Paper 150, WCC Publications, Genewa 1990, s. 16-24.

Wspólna Grupa Robocza Kościoła Rzymskokatolickiego i Światowej Rady Kościołów, Szósty Oficjalny Raport (1990), „Studia i Dokumenty Ekumeniczne” 8 (1992) nr 2, s. 47-69.

Wspólna Grupa Robocza Kościoła Rzymskokatolickiego i Światowej Rady Kościołów, Pojęcie "hierarchia prawd” - interpretacja ekumeniczna. Dokument studyjny, „Studia i Dokumenty Ekumeniczne” 8 (1992) nr 2, s. 85-93.

\section{Is there a „Hierarchy of Councils”? An Ecumenical Perspective}

\section{SUMMARY}

Theologians recognize several types of „hierarchy” in reference to the authority of Church councils and their resolutions. Most Christian traditions give priority to seven councils of the first millennium. The Orthodox church acknowledges only seven councils as universal (ecumenical). Some believe that the first four councils that formulated the doctrine of the mystery of the Trinity and Christ should occupy a privileged place. It has been proposed to distinguish between universal councils of the first millennium and general councils of the Western Church in the second millennium or make distinctions between universality (ecumenicity) of councils de facto and de iure. Also, it is important to take into account the difference between the councils that defined the faith and those which dealt with disciplinary issues. The discussion about "hierarchy of councils" is not finished, but it has already introduced an important sense of proportion into the ecclesiological and ecumenical reflection. 
KEYWORDS: Congar Yves, council, ecumenism, hierarchy, Joint Working Group of the Ecumenical Council of Churches and the Roman Catholic Church, Paul VI

SŁOWA KLUCZOWE: Congar Yves, ekumenizm, hierarchia, Paweł VI, sobór, Wspólna Grupa Robocza Światowej Rady Kościołów i Kościoła Rzymskokatolickiego 